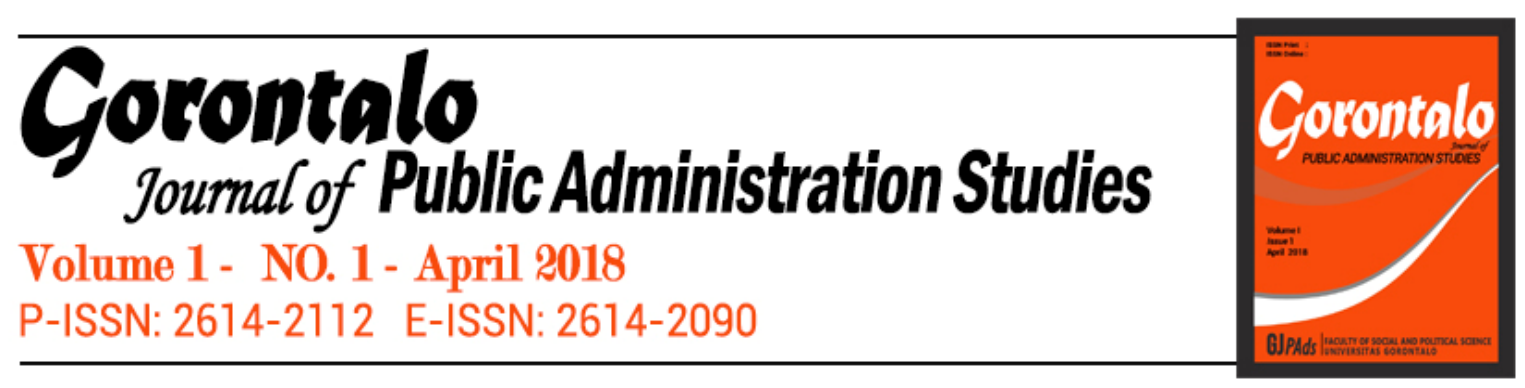

\title{
Kekuatan Politik Perempuan dalam Organisasi Partai Keadilan Sejahtera (PKS) di Kabupaten Gorontalo
}

\author{
Program Studi Administrasi Publik, Universitas Gorontalo \\ Dewi.walahe31@gmaill.com
}

\begin{abstract}
The purpose of this study is to know the political power of women in the organization of Prosperous Justice Party (PKS) in Gorontalo District. The research method used is quantitative method, and research type is descriptive. Data collection using questionnaires, interviews, observation and documentation. The research informant is the leader of the PKS Party of Gorontalo district. The result of the research shows that 1) the representation of women in the governance of the PKS party in Gorontalo Regency has not been able to fulfill women's representation $30 \%$ in the management of political parties according to Law no. 2 Year 2008 Jo. Law no. 2 Year 2011 on Political Parties. 2) There are four factors that inhibit the fulfillment of $30 \%$ of women's representation until it is not fulfilled: First, from the normative point, the Law regulating it is Law no. 2 Year 2008 Jo. UU no. 2 Year 2011 on political parties is not effective in the implementation process. Second, the cultural factor, patriarchal culture, where is men have a higher position than women; third, the Political Party Factor itself. The party sometimes never gives women the opportunity to occupy strategic positions in party stewardship so women are sometimes overlooked; and fourth, the factor of the woman's personal. Indonesian women are still a lot of pessimists or feel afraid of themselves.
\end{abstract}

Keywords: woman representation; PKS Party; Gorontalo Regency.

ABSTRAK
Tujuan penelitian ini adalah untuk mengetahui kekuatan politik perempuan dalam organisasi Partai Keadilan Sejahtera (PKS) di Kabupaten Gorontalo. Metode penelitian yang digunakan adalah metode kuantitatif, dan jenis penelitiannya adalah deskriptif. Pengumpulan data menggunakan kuesioner, wawancara, observasi dan dokumentasi. Informan penelitian adalah pemimpin Partai PKS Kabupaten Gorontalo. Hasil penelitian menunjukkan bahwa: 1) keterwakilan perempuan dalam tata kelola partai PKS di Kabupaten Gorontalo belum mampu memenuhi keterwakilan perempuan $30 \%$ dalam pengelolaan partai politik sesuai dengan UU no. 2 Tahun 2008 Jo. UU no. 2 Tahun 2011 tentang Partai Politik. 2) Ada empat faktor yang menghambat pemenuhan $30 \%$ representasi perempuan sampai tidak terpenuhi: Pertama, dari titik normatif, UU yang mengaturnya adalah UU No. 2 Tahun 2008 Jo. UU No. 2 Tahun 2011 tentang partai politik tidak efektif dalam proses implementasi. Kedua, faktor budaya, budaya patriarki, di mana memiliki posisi yang lebih tinggi daripada perempuan; ketiga, Faktor Partai Politik itu sendiri. Partai kadang-kadang tidak pernah memberi perempuan kesempatan untuk menduduki posisi strategis dalam kepengurusan partai sehingga perempuan kadang-kadang diabaikan; dan keempat, faktor pribadi wanita itu. Wanita Indonesia masih banyak pesimis atau merasa takut pada dirinya sendiri.

Kata Kunci: representasi perempuan; Partai PKS; Kabupaten Gorontalo. 


\section{PENDAHULUAN}

Salah satu tujuan dalam Sasaran Pembangunan Berkelanjutan (Sustainable Development Goals atau SDGs) adalah kesetaraan gender dan pemberdayaan perempuan. Artinya, diharapkan di abad sekarang ini, tidak ada lagi bentuk diskriminasi yang dialami oleh kaum perempuan terhadap dominasi laki-laki. Harus diakui sampai saat ini peran perempuan dalam pembangunan milenium belumlah sesuai dengan harapan. Hal Ini dapat dilihat dalam penempatan perempuan terhadap suatu jabatan, dimana laki-laki selalu mendominasi.

Kendala struktural tersebut sering kali berkaitan dengan permasalahan pendidikan, status sosial, ekonomi, dan pekerjaan. Sampai saat ini, pekerjaan perempuan masih sering diidentikkan dengan pekerjaan yang sulit berimbang dengan kaum laki-laki. Sementara kendala kultural terkait dengan faktor budaya yang hidup dalam masyarakat seperti menempatkan perempuan untuk sekedar tinggal di rumah. Kini konsep kesetaraan gender dianggap sebagai sebuah jawaban untuk mengatasi persoalan perempuan tersebut. Gerakan ini sudah berkembang menjadi gerakan massal yang sangat berpengaruh.

Reformasi yang dialami bangsa Indonesia pada tahun 1998 membawa perubahan pada sistem politik dan struktur ketatanegaraan Indonesia. Perubahan ini membuka peluang bagi setiap elemen bangsa untuk terlibat di dalamnya untuk menuju kehidupan demokrasi yang lebih baik. Bagi kaum perempuan di Indonesia, perubahan sistem politik dan ketatanegaraan ini juga memberi harapan bagi mereka untuk dapat memperjuangkan kepentingannya dengan lebih nyata karena realisasi dari perubahan struktur ketatanegaaan dan sistem politik Indonesia adalah diamandemennya Undang-Undang Dasar Tahun 1945 (selanjutnya disebut UUD 1945). Dalam proses perubahan UUD 1945, memuat beberapa Pasal yang memberikan hak-hak kepada warga Negara.

Pasal-pasal tersebut memberikan sebuah konsekuensi logis terhadap setiap orang dalam arti warga negara Indonesia baik laki-laki ataupun perempuan untuk memperjuangkan haknya secara kolektif tanpa ada perlakuan yang bersifat diskriminatif. Jadi secara tidak langsung, perubahan terhadap UUD 1945 memberikan konsekuensi logis terhadap persamaan kedudukan antara perempuan dan laki-laki karena selama ini dapat dilihat bagaimana peran perempuan dalam dunia politik sangatlah kurang.

Akibat dari hal tersebut, sistem pemilihan umum (pemilu) setelah reformasi juga mengalami perubahan. Hal ini ditandai dengan diberlakukannya Undangundang Nomor 2 Tahun 1999 dan setelah itu dirubah menjadi Undang-undang Nomor 2 Tahun 2008 Jo. Undang-undang Nomor 2 Tahun 2011 yang dalam beberapa pasalnya, menyebutkan :

1. Pasal 2 ayat (2) : "Pendirian dan pembentukan Partai Politik sebagaimana dimaksud pada ayat (1) menyertakan 30\% (tiga puluh perseratus) keterwakilan perempuan.

2. Pasal 2 ayat (5) : "Kepengurusan Partai Politik tingkat pusat sebagaimana dimaksud pada ayat (3) disusun dengan menyertakan paling rendah $30 \%$ (tiga puluh perseratus) keterwakilan perempuan.

3. Pasal 20 : "Kepengurusan Partai Politik tingkat provinsi dan kabupaten/kota sebagaimana dimaksud dalam Pasal 19 ayat (2) dan ayat (3) disusun dengan memperhatikan keterwakilan perempuan paling rendah 30\% (tiga puluh perseratus) yang diatur dalam AD dan ART Partai Politik masing-masing." 
Diberikannya angka 30\% pada beberapa pasal dalam Undang-Undang Partai Politik tersebut merupakan sebuah kebijakan yang dilakukan oleh pembentuk undang-undang yaitu Pemerintah dan DPR dalam upaya memberdayakan kaum perempuan di Indonesia agar mempunyai kesempatan yang sama untuk berpartisipasi dalam dunia politik, khususnya masuk dalam struktur kepengurusan partai politik.

Kebijakan tersebut merupakan sebuah kebijakan affirmative action atau pemberian perlakuan khusus. Khusus untuk di Indonesia, pemberian perlakuan khusus yang diberikan kepada kaum perempuan merupakan upaya meningkatkan keikutsertaan perempuan dalam dunia politik seperti keterwakilan perempuan dalam Lembaga DPRD. Dengan adanya kebijakan tersebut, diharapkan keterwakilan perempuan dalam kepengurusan partai politik sesuai UU No. 2 Tahun 2008 Jo. UU No. 2 Tahun 2011 tentang Partai Politik tersebut, setiap partai politik yang mempunyai fungsi rekrutmen politik dan pendidikan politik dapat memberdayakan kaum perempuan dalam kepengurusannya.

Realita yang terjadi saat ini, pemenuhan angka 30\% dalam kepengurusan partai politik berbanding terbalik dengan pemenuhan kuota perempuan yang duduk di DPRD. Target yang ingin dicapai yaitu 30\% untuk perempuan di DPRD tidak terpenuhi walapun dalam setiap periode selalu mengalami peningkatan. Selain itu sampai saat ini belum mencapai target 30\%, pencantuman $30 \%$ dalam beberapa undang-undang yang mengatur tentang keterwakilan perempuan masih menjadi sebuah perdebatan, apakah pencatuman angka 30\% tersebut telah melanggar hak asasi perempuan yang dijamin secara konstitusional dalam UUD 1945, bahwa setiap warga Negara berhak memperoleh kesempatan yang sama dalam pemerintahan Di sisi lain, timbul pertanyaan mengapa yang diatur dalam undang-undang hanya 30\%, mengapa tidak lebih daripada itu. Kemudian dicantumkannya angka 30\% keterwakilan perempuan dalam undang-undang tersebut membuat partai politik yang ingin merekrut perempuan dalam partai politiknya, hanya merekrut keterwakilan perempuan sebesar $30 \%$ dan tidak akan lebih dari jumlah tersebut, sehingga perempuan tetaplah mendapat diskriminasi di bidang politik.

\section{KAJIAN TEORI}

\subsection{Konsep Gender}

Kata gender dalam istilah bahasa Indonesia sebenarnya berasal dari bahasa Inggris, yaitu "Gender ". Jika di lihat dalam kamus bahasa Inggris, tidak secara jelas di bedakan pengertian anatar sex dan gender. sering kali gender di persamakan dengan seks jenis kelamin laki- laki dan perempuan. (Nugroho 2011 : 01)

Di sadari bahwa gender merupakan isu baru bagi masyarakat, sehingga menimbulkan berbagai penafsiran, dan respon yang tidak proporsional tentang gender. Salah satu faktor yang mempengaruhi adanya kesenjangan gender adalah bermacam-macamnya tafsiran tentang pengertian gender dalam kaitannya dalam usaha emansipasi kaum perempuan. Setidaknya ada beberapa penyebab terjadinya ketidak jelasan dan kesalapahaman tersebut. Setelah sekian lama terjadi proses pembagian peran dan tanggung jawab terhadap kaum laki - laki dan perempuan yang telah berjalan bertahun - tahun bahkan berabad - abad maka sulit 
dibedakan pengertian antara seks (laki- laki dan perempuan) dengan gender (Nugroho 2011: 02).

Istilah Gender pertama kali di perkenalkan Nugroho mengikhtisar beberapa teori antara lain oleh Robert Stoller (1968) untuk memisahkan pencirian manusia yang di dasarkan pada pendefinisian yang bersifat sosial budaya dengan pendefinisianyang berasal dari ciri-ciri fisik biologis. Dalam ilmu sosial orang yang juga sangat berjasa dalam mengembangkan istilah dan pengertian gender ini adalah Ann Oakley (1972). Sebagaimana Stoler, Oakley mengartikan Gender sebagai konstruksi sosial atau atribut yang dikenakan pada manusia yang dibangun oleh kebudayaan manusia. (Nugroho 2011: 02).

Pada sumber lain Oakley (1972) dalam Sex, Gender and Society. Menuturkan bahwa gender berarti perbedaan yang bukan biologis dan bukan kodrat Tuhan. Perbedaan biologis merupakan perbedaan jenis kelamin (sex) adalah kodrat tuhan maka secara permanen berbeda dengan pengertian gender. Gender merupakan behavioral differences (perbedaan perilaku) anatara laki-laki dan perempuan yang dikonstruksi secara sosial, yakni perbedaan yang bukan ketentuan Tuhan melainkan di ciptakan oleh manusia (bukan kodrat) melalui proses sosial dan kultural yang panjang. Dalam The Cultural Construction of Sexuality sebagaimana yang diuraikan oleh Caplan (1987) bahwa behavioral differences (perbedaan perilaku) antara perempuan dan laki- laki bukanlah sekedar biologis, namun melalui proses cultural dan sosial. Dengan demikian, gender dapat berubah dari tempat ke tempat, dari waktu ke waktu, bahkan dari kelas ke kelas, sedangakan jenis kelamin akan tetap tidak berubah. (Nugroho 2011: 03)

\subsection{Konsep Representatif (Keterwakilan)}

Represntatif adalah orang-orang yang terpilih atau perwakilan bersifat mewakili. Sebagai salah contoh adalah ketika seseorang yang berminat untuk mencalonkan diri sebagai masyarakat kemudian terpilih sebagai wakil rakyat dari daerah pilihnya (Gaffar 2006: 408).

Representatif atau keterwakilan pada dasarnya adalah orang yang dipilih yang menjadi katerwakilan atau representatif namun pilihan tersebut semua didasrkan dan diserahkan pada masyarakat atau orang yang memilih karena pemilihan adalah penyerahan hak yang memilih kepada orang yang dipilih atau mencalankon diri, karena dalam pasal 1 ayat 2 Undang-Undang Dasar 1945 dinyatakan dengan tegas, bahwa "kedaulatan ada ditangan rakyat dan dilakukan sepenuhnya oleh majelis permusyrawatan rakyat, artinya rakyat pada dasarnya memiliki kekuasaan dalam kehidupan bernegara (Gaffar 2006: 281).

Disadari atau tidak bahwa perempuan mempunyai kesetaraan dengan lakilaki yang disebut gender. Sesuai dengan perundang-undangan di Negara kita lebih khsusnya mengenai UU No 10 Tahun 2008 Tentang Pemilu Anggota DPR, DPD dan DPRD yang memberikan kuota 30\% untuk keterwakilan perempuan. makin memberikan jaminan peluang bagi peningkatan keterwakilan perempuan diarena politik, mau tidak mau perempuan harus mempunyai keterwakilan dalam jabatan legeslatif, sehingga akan terjadi sebuah keseimbangan di legeslatif nanti. (UU No 10/2008 tentang Pemilihan Umum). 
Berbicara tentang keterwakilan perempuan, tidak terlepas dari bagaimana mengupayakan dan memberdayakan kaum perempuan itu sendiri. Pemberdayaan perempuan yang dimaksud adalah suatu upaya sistematik dan terencana untuk melibatkan perempuan dalam berbagai program pembangunan dengan memberikan kesempatan dan peran yang sama dengan laki-laki untuk meningkatkan produktivitas, harkat dan martabat serta integritasnya sebagai individu anggota masyarakat.

Pemberdayaan perempuan yang dimaksud disini merupakan tindakan mengintegrasikan program-program pembangunan ke dalam aktivitas yang lebih nyata, termasuk dalam ranah hukum dan politik, dimana perempuan dan lakilaki mendapatkan porsi kesempatan yang sama untuk berperan aktif dalam meningkatkan aksesibilitas sumber daya di semua sektor. Dalam hubungan inilah program-program pemberdayaan perempuan (women of empower) dipandang sebagai bagian dari pelaksanaan hak-hak asasi manusia yang berlaku universal.

United Nation of Organization merumuskan beberapa gagasan yang berkaitan dengan pemberdayaan perempuan, yakni :

1. Penanggulangan kemiskinan.

2. Keterlibatan semua orang secara adil dalam perekonomian.

3. Perbaikan khualitas hidup perempuan dan laki-laki berkenaan dengan akses terhadap barang dan jasa yang esensial serta informasi yang dibutuhkannya untuk membuat pilihan.

4. Penciptaan basis-basis produktif untuk memenuhi kebutuhan penduduk dan memungkinkan keadaan perekonomian negara berubah.

5. Pembagian kerja secara seksual.

6. Penghargaan terhadap nilai kultur dan aspirasi berbagai kelompok sosial.

Khusus untuk indonesia sendiri upaya pemberdayaan perempuan untuk mengoptimalkan keterwakilan perempuan dalam setiap jabatan publik telah dilakukan dengan mengeluarkan beberapa peraturan perundang-undangan menyangkut hal tersebut. Adanya pemberdayaan perempuan tersebut tidak lepas dari delegasi UUD NRI Tahun 1945 yang telah menjelaskan dalam beberapa pasalnya antara lain :

1. Pasal 28C ayat (2) "Setiap orang berhak memajukan dirinya dalam memperjuangkan haknya secara kolektif untuk membangun masyarakat, bangsa, dan negaranya.

2. Pasal 28D ayat (3) "Setiap Warga Negara berhak memperoleh kesempatan yang sama dalam pemerintahan.

3. Pasal 28I ayat (2)" Setiap orang berhak bebas dari perlakuan diskriminatif atas dasar apapun dan berhak mendapatkan perlindungan terhadap perlakuan yang bersifat diskriminatif itu."

Pasal-Pasal dalam UUD 1945 diatas yaitu Pasal 28C ayat (2), 28D ayat (3) dan 28I ayat (2) telah memberikan sebuah penafsiran bahwa antara laki-laki dan perempuan tidak ada perbedaan dalam konteks perebedaan gender atau penempatan jabatan publik bahwa mereka sama kedudukan didalam hukum dan pemerintahan. Sehingga adanya prasyarat didalam UUD NRI Tahun 1945 tersebut melahirkan beberapa undang-undang yang mengatur tentang keikutsertaan perempuan dalam dunia politik. Dan sampai saat ini, ada dua 
undang-undang yang mengatur tentang bagaimana keikutsertaan perempuan dalam dunia politik. pertama, UU No.2 Tahun 2008 Jo. UU No.2 Tahun 2011 tentang Partai Politik. Seperti dalam Pasal 2 ayat (2) disebutkan bahwa "Pendirian dan pembentukan Partai Politik sebagaimana dimaksud pada ayat (1) menyertakan 30\% (tiga puluh perseratus) keterwakilan perempuan." Atau di ayat (5) disebutkan "Kepengurusan Partai Politik tingkat pusat sebagaimana dimaksud pada ayat (2) disusun dengan menyertakan paling sedikit 30\% (tiga puluh perseratus) keterwakilan perempuan."

Pasal yang kedua, yaitu UU No.10 Tahun 2008 tentang pemilihan anggota DPR, DPD dan DPRD. Ada juga beberapa Pasal yang mengatur tentang bagaimana peran perempuan tersebut. Dalam Pasal 8 ayat 1 huruf (d) disebutkan "Partai politik dapat menjadi peserta pemilu setelah memenuhi persyaratan, yaitu (d) menyertakan sekurang-kurangnya 30\% (tiga puluh perseratus) keterwakilan perempuan pada kepengurusan partai politik tingkat pusat"

UU tentang partai politik tersebut mengatur tentang bagaimana peran perempuan dalam sebuah kepengurusan partai politik baik di tingkat pusat maupun di tingkat daerah. Sedangkan UU tentang DPR, DPD dan DPRD mengatur tentang bagaimana Perempuan tersebut berada dalam sebuah lembaga Perwakilan baik itu DPR, DPD maupun DPRD. Di dalam kedua UU tersebut mengatur tentang perlakuan khusus terhadap kaum perempuan atau affirmative action. Affirmative action ini memberikan peluang kepada keterwakilan perempuan dalam sebuah partai politik. Disebutkan bahwa setidaknya partai politik yang berdiri menyertakan sekurang-kurangnya $30 \%$ (tiga puluh persen) keterwakilan perempuan dalam kepengurusan partai politiknya. Diharapkan dalam sebuah partai politik yang mempunyai fungsi rekrutmen politik dan sosialisasi politik dapat memberikan sebuah pendidikan politik kepada kaum perempuan agar mereka mempunyai keinginan untuk memperjuangkan hak politiknya.

Sebenarnya sampai saat ini menjadi sebuah dilema di Negara Indonesia terhadap keterwakilan perempuan. Saat ini walaupun pemerintah telah mengupayakan beberapa kebijakan yang dimaksudkan untuk memberdayakan perempuan ternyata belum terwujud sepenuhnya, karena sampai saat ini perempuan masih mendapat tempat berbeda dibandingkan laki-laki. Secara realitas sampai saat ini dalam penempatan kursi terhadap kebijakan-kebijakan publik ternyata belum dapat membuat perempuan mendapat tempat yang setara dengan laki-laki. Belum lagi di dalam DPR, dimana diharapkan angka $30 \%$ tersebut dapat dipenuhi ternyata tidak terjadi.

Setelah reformasi, mulai dari pemilu 1999 sampai 2009 saat ini, perempuan masih mendapat tempat lebih rendah dibanding laki-laki. Pemilu 1999 hanya menempatkan keterwakilan perempuan 9,0\% di DPR, Pemilu 2004 menepatkan keterwakilan perempuan hanya sekitar 10,7\% dan pemilu 2009 hanya menempatkan keterwakilan perempuan sebanyak 17,6\%.

Walaupun dalam kenyataannya tiap tahunnya mengalami peningkatan, tetap saja tidak dapat membuat pencapaian angka yang seharusnya bagi kaum perempuan untuk mendapatkan hak politiknya di dalam DPR. Jadi untuk mengoptimalkan hal tersebut, pemerintah harus terus berupaya agar bagaimana pemberdayaan perempuan tersebut dapa ditingkatkan. 


\subsection{Regulasi Keterwakilan Perempuan}

Upaya mendorong keterwakilan perempuan dalam politik terus disuarakan oleh sebagian orang, sehingga konstitusi atau komisi pemilihan umum telah mengambil keputusan untuk mengorbitkan perempuan disektor politik yang telah di atur berdasarkan UU No 10/2008 tentang Pemilihan Umum Anggota Dewan Perwakilan Rakyat, Dewan Perwakilan Daerah, dan Dewan Perwakilan Rakyat Daerah (pemilu legislatif) serta UU Nomor 02/2008 tentang Partai Politik telah memberikan mandat kepada parpol untuk memenuhi kuota $30 \%$ bagi perempuan dalam politik, terutama di lembaga perwakilan rakyat. (UU 02/2008 tentang Parpol).

Pada pelaksanaan pemilu 2009, peraturan perundang-undangan yang telah mengatur kuota 30\% perempuan bagi partai politik (parpol) dalam menempatkan calon anggota legislatifnya. Undang-Undang (UU) Nomor 10/2008 Pasal 8 butir d UU Nomor 10/2008, misalnya, menyebutkan penyertaan sekurang-kurangnya $30 \%$ keterwakilan perempuan pada kepengurusan parpol tingkat pusat sebagai salah satu persyaratan parpol untuk dapat menjadi peserta pemilu. Selain itu, Pasal 53 UU Pemilu Legislatif tersebut juga menyatakan daftar bakal calon juga memuat paling sedikit 30\% keterwakilan perempuan.

\section{METODOLOGI PENELITIAN}

\subsection{Jenis Penelitian}

Jenis penelitian ini yang digunakan adalah penelitian lapangan (field research). Penelitian dilakukan dengan memgambil sumber data dari dokumentasi terhadap keterwakilan perempuan di Partai Keadilan Sejahtera Kabupaten Gorontalo. Kemudian dideskripsikan dan dianalisis sehingga dapat menjawab terhadap persoalan yang telah dirumuskan dalam pokok masalah.

Dalam menganalisis data pada penelitian ini penyusun menggunakan dua jenis data yaitu : 1) Data primer, yaitu data yang diperoleh langsung dari dokumentasi PKS Kabupaten Gorontalo serta narasumber yang diwawancarai, 2) Data sekunder, semua informasi yang berkaitan dengan kedudukan/ keterwakilan perempuan dalam kepengurusan Partai Keadilan Sejahtera Kabupaten Gorontalo, baik berupa buku-buku penunjang, undang-undang, pendapat para tokoh dan pendapat dari aktifis perempuan.

\subsection{Lokasi dan Waktu Penelitian}

Melihat subyek dalam penelitian ini adalah keterwakilan Perempuan dalam pengurus Partai Keadilan Sejahtera maka lokasi penelitian adalah DPD Partai Keadilan Sejahtera Kabupaten Gorontalo. penelitian ini berlangsung selama \pm 2 (dua) bulan.

\subsection{Populasi dan Sampel}

Populasi penelitian dapat ditemukan dengan memilih informan untuk dijadikan informan kunci di dalam data lapangan. Dengan demikian subjek penelitian merupakan sumber informasi mencari data dan masukan-masukan dalam mengungkapkan masalah penelitian, adapun informasi adalah orang yang dimanfaatkan untuk memberikan informasi tentang situasi dan kondisi latar belakang penelitian. Jadi ia harus mempunyi banyak pengalaman tentang latar belakang penelitian.

Dalam penelitian ini yang menjadi penelitian adalah 1) perempuan dalam kepegurusan Partai Politik Keadilan Sejahtera Kabupaten Gorontalo, 2) 
Keterwakilan perempuan Partai Keadilan Sejahtera dalam perlemen di tingkat DPRD Kabupaten Gorontalo.

\subsection{Sumber Data}

Dalam penelitian ini, penyusun akan mempergunakan jenis data yang meliputi data sekunder dan data primer yang berkaitan dibidang politik yang berkaitan keterwalian perempuan dalam politik. Data primer adalah data yang diperoleh langsung dari sumber pertama melalui penelitian lapangan. Sedangkan data sekunder antara lain mencakup dokumen-dokumen resmi, buku-buku, hasil-hasil penelitian yang berwujud laporan, buku harian, dan lain-lain.

\subsection{Teknik Pengumpulan Data}

Pengumpulan data dilakukan dengan observasi, wawancara dan dokumentasi. Metode observasi ini digunakan penyusun guna pengumpulan data melalui pengamatan dan peninjuan langsung dilapangan atau lokasi penelitian. Dalam hal ini, penyusun mengunjungi lokasi penelitian agar mengetahui secara langsung kondisi di lapangan. Penemuan ilmu pengetahuan selalu dimulai dengan observasi dan kembali pada observasi untuk membuktikan kebenaran ilmu pengetahuan tersebut.

Metode wawancara adalah wawancara digunakan untuk melengkapi atau mendukung hasil penelitian, peneliti bisa menggali informasi tentang topic penelitian secara mendalam yaitu menghubungi dan bertanya secara langsung kepada pihak-pihak terkait guna mendapatkan data dan informasi di lapangan. Adapun pihak-pihak terkait adalah para perempuan yang menjabat sebagai pengurus partai politik Keadilan Seajahtera ataupun yang menjabat di DPRD Kabupaten Gorontalo. Metode dekomentasi adalah mencari data-data yang variabel yang berupa catatan, buku-buku, dan lain sebagainya. Metode ini digunakan pada saat penelusuran informasi yang bersumber dari dokumentasi objek bersangkutan dan yang mempunyai relevensi dengan tujuan penelitian.

\subsection{Teknik Analisa Data}

Analisis data adalah proses mencari dan menyusun secara sistematis data yang diperoleh dari hasil wawancara, catatan lapangan, dan dokumentasi melalui cara mengorganisasikan data kedalam kategori, menjabarkan hala-hal penting dan membuat kesimpulan sehingga mudah difahami oleh peneliti dan pembaca. Adapun metode analisis yang digunakan adalah metode analisis kulitatif yang bersifat deduktif. Artinya suatu analisis berdasarkan data yang diperoleh, kemudian dikembangkan sesuai dengan pola tertentu atau menjadi hipotesis serta analisis data dari yang bersifat khusus, kemudian ditarik konklusi yang dapat menggeneralisasikan menjadi kesimpulan yang bersifat umum.

\section{HASIL PENELITIAN DAN PEMBAHASAN}

Dalam Anggaran Dasar Partai Keadilan Sejahtera (PKS) BAB XI Dewan Pengurus Daerah pasal 17 ayat 2 menyebutkan dewan pengurus tingkat daerah berkedudukan di ibu kota kabupaten atau kota. Dewan Pengurus Daerah (DPD) Partai Keadilan Sejahtera (PKS) Kabupaten Gorontalo, merupakan Dewan Pengurus Daerah (DPD) Partai Keadilan Sejahtera (PKS) yang berkedudukan di ibu kota kabupaten atau kota, koordinator dan 
penanggung jawab musyarawah Dewan Pengurus Daerah adalah ketua majelis pertimbangan Daerah.

Dewan Pengurus Daerah Partai Keadilan Sejahtera (PKS) Kabupaten Gorontalo, menaungi Dewan Pengurus Ranting yang berada dalam kekuasaannya, Dewan Pengurus Ranting merupakan kepengurusan partai pada tingkat kecamatan, Dewan Pengurus Daerah Partai Keadilan Sejahtera (PKS) Kabupaten Gorontalo berdiri sejak tanggal 20 April 1998, jadi Dewan Pengurus Daerah Partai Keadilan Sejahtera (PKS) Kabupaten Gorontalo sudah berusia 18 tahun.

Struktur organisasi Partai Keadilan Sejahtera (PKS) sesuai yang diatur dalam Anggaran Dasar Partai Keadilan Sejahtera (PKS) yaitu struktur organisasi partai tingkat pusat Partai Keadilan Sejahtera (PKS) terdiri, Majelis Syuro, Dewan Syariah, Dewan Pengurus Pusat, dan Dewan Syari'ah Pusat, sedangkan struktur organisasi tingkat propinsi terdiri dari Majelis Pertimbangan Wilayah, Dewan Pengurus Wilayah, dan Dewan Syari'ah Wilayah yang berkedudukan pada tingkat propinsi, dalam ruang lingkup kepengurusan tingkat propinsi atau wilayah didirikan struktur organisasi tingkat daerah atau kabupaten/kota yang berkedudukan di kabupaten atau kota. Dewan Pengurus Daerah Kabupaten Gorontalo terdiri dari ketua, sekertaris, bendahara, bidang kaderisasi atau pembinaan kader, bidang pembangunan keumatan, bidang kebijakan publik dan pengembangan ekonomi kewirahusahaan, bidang kepanduan dan olahraga, bidang generasi muda dan profesi, bidang perempuan, bidang kelembagaan sosial,dan Dewan pakar. Struktur atau susunan pengurus Partai Keadilan Sejahtera (PKS) Kabupaten Gorontalo sebagai berikut :

Ketua

Wakil Ketua

Sekertaris

Bendahara

Bidang Pembinaan Kader
: Zaitun K. Djabi, SH

: Harto Moomin

: Steven J. Ekie, ST

: Ervina Yamin, SE

: Ridwan Umar, S.KOM

Dalam penelitian ini, dapat ditemukan gambaran mengenai Dewan Pengurus Daerah (DPD) Partai Keadilan Sejahtera (PKS) untuk anggota Pengurus Partai di Kabupaten Gorontalo. Berdasarkan hasil wawancara dengan Ketua Partai Keadilan Sejahtera (PKS) Kabupaten Gorontalo yaitu Bapak Zaitun K. Djabi, SH pada Senin, 4 April 2017 dapat diketahui bahwa upaya Dewan Pengurus Daerah (DPD) Partai Keadilan Sejahtra (PKS) untuk mengisi ketrewakilan Anggota perempuan sebagai pengusus partai PKS di Kabupaten Gorontalo Masih belum sepenuhnya memenuhi kuota 30\% di sebabkan banyak kendala sehingga masih banyak struktur yang kosong, bahkan stuktur kepengurusan PKS yang baru ini di oleh 5 dan satu orang perempuan. kurangnya kesediaan kader perempuan dari partai PKS untuk menjadi pengurus selain itu factor penghambat minimnya pendidikan pormal bagi kader partai PKS, sehingga memang belum sepenuhnya kami sebagai pengurus partai menjalankan amanat dari pada Undang-Undang no 2 tahun 2008 dan undang-undang no 2 tahun 2011.

Dari perspektif sosial, sampai saat ini ketertinggalan perempuan dari berbagai dimensi kehidupan sangatlah besar. Ini dapat dilihat dari data Human Development Report (HDR) yang menunjukkan bahwa pembangunan gender di 
Indonesia amat rendah, yaitu di peringkat ke-90 dunia. Ini menujukkan bagaimana tingkat diskriminasi perempuan yang begitu besar. Kemudian ditunjukkan bagaimana disparitas antara laki-laki dan perempuan terjadi di hampir semua lini. Di bidang pendidikan, sebanyak $11,56 \%$ perempuan belum mengenyam pendidikan, sedangkan laki-laki yang belum mengenyam pendidikan hanya 5,43\%. Angka buta aksara perempuan sebesar 12,28\%, sedangkan laki-laki 5,84\%. Dalam bidang kesehatan, status gizi perempuan juga masih merupakan masalah utama. Angka kematian ibu (AKI) juga masih sangat tinggi, yaitu sebesar 248 per 100.000 kelahiran hidup. Di bidang ekonomi, tingkat partisipasi angkatan kerja (TPAK) laki-laki jauh lebih tinggi $(86,5 \%)$ daripada perempuan (50,2\%). Dalam ranah birokrasi, dari 3.741 .495 orang, sebanyak $1.550 .024(41,43 \%)$ adalah perempuan. Angka itu memang terlihat cukup tinggi, tetapi karier perempuan dalam birokrasi belum mendapatkan ruang yang adil.

Dari Pejabat Eselon 1 yang berjumlah 645 orang, perempuan hanya sejumlah 63 orang $(9,7 \%)$. Adapun pada jabatan eselon II yang berjumlah 11.255 orang, jumlah perempuannya baru 755 orang $(6,71 \%)$. Kemudian kasus kekerasan terhadap perempuan meningkat tajam, dari 25.522 kasus (2007) menjadi 54.425 kasus (2008) dan dari data tahun 2009-2010, jumlah kekerasan terhadap perempuan mencapai 143.586 kasus. Angka ini meningkat sebesar 263\% dibandingkan tahun sebelumnya. Dari jumlah kasus tersebut, sebagian besar $(82 \%)$ merupakan kasus KDRT. Angka kejahatan trafficking juga masih tinggi. Setiap tahun lebih dari 100.000 anak dan perempuan diperdagangkan dan dilacurkan.

Maka daripada itu, diharapakan dengan dicantumkannya angka 30\% keterwakilan perempuan dalam kepengurusan partai politik dalam UU No. 2 Tahun 2008 jo. UU No. 2 Tahun 2011 tentang partai politik dapat meningkatkan pemberdayaan partisipasi politik perempuan di Indonesia agar kedepannya tidak ada lagi bentuk-bentuk diskriminasi yang dialami oleh perempuan-perempuan Indonesia dan angka ketertinggalan perempuan dari segala dimensi bisa diminimalisir secara bertahap dengan kebijakan-kebijakan negara yang bersifat membangun.

Diterangkan oleh Ibu Ervina Yamin, SE yang merupakan Bendahara DPD PKS Kabupaten Gorontalo dalam wawancara tanggal 9 april 2017, bahwa sebenarnya dasar pertimbangan sehingga dicantumkannya angka 30\% dalam UU No. 2 tahun 2008 Jo. UU No. 2 Tahun 2011 tentang partai politik adalah karena dorongan dari organisasi-organisasi perempuan yang ada di Indonesia dulu yaitu KPPI (Kaukus Perempuan Politik Indonesia) yang sangat mengupayakan agar perempuan juga mendapat tempat yang setara dengan lakilaki di dunia politik. Karena selama ini laki-laki selalu mendominasi di berbagai bidang, semua jabatan-jabatan publik dan kursi yang ada di DPR, DPRD, ataupun dalam kepengurusan partai politik selalu didominasi oleh laki-laki. Diharapkan suatu hari akan dirancang sebuah undang-undang yang dimana perempuan dapat diberikan perlakuan khusus agar mendapat tempat yang setara dengan laki-laki. Akhirnya pada tahun 2008, tepatnya ketika UU No. 2 Tahun 2008 tentang Partai Politik disetujui oleh DPR RI, lahirlah sebuah undang-undang yang memberikan kontribusi terharap perkembangan perempuan di Indonesia karena dalam undang-undang tersebut mewajibkan 
setiap partai politik yang ingin mengkuti pemilu harus menyertakan keterwakilan perempuan sebanyak 30\%.

Walaupun sampai saat ini apa yang diharapkan belum mencapai target keterwakilan perempuan yang ada di DPRD Kabupaten Gorontalo. Untuk mencapai kuota 30\%. Keterwakilan perempuan di DPRD hanya diwakili 6 perempuan dari anggota DPRD atau sebesar 1,8\% dari 30 anggota DPRD kabupaten Gorontalo periode 2014-2019. Itupun 6 orang perempuan yang berada di DPRD Kabupaten Gorontalo tidak ada ketrwakilan atau 0\% dari Partai Keadilan Sejahtera sebagai objek penelitian. sehinga ini bisa menjawab Dasar Pertimbangan pada Penentuan Keterwakilan Perempuan 30\% Dalam Kepengurusan Partai Politik Menurut Undang-Undang No. 2 Tahun 2008 Jo. Undang-Undang No. 2 Tahun 2011 Tentang Partai Politik Ditinjau Dari Perspektif Hak Asasi Manusia (HAM) belum sepenuhnya partai keadilan sejahtera menjalankan amanat dari pada undang-undang tersebut.

Keterwakilan perempuan Partai PKS yang mencalonkan menjadi anggota legislatif pada tahun 2014 cukup terwakilkan untuk mencapai kuota 30\% dari 5 Daerah pemilihan yang ada di Kabupaten Gorontalo, Daearah pemilihan 1 di wakili oleh 3 orang (42\%) perempuan dari 7 oarang $(58 \%)$ calon anggota legislatif, derah pemilihan 2 diwakili 3 orang $(42 \%)$ dari 7 orang $(58 \%)$ calon anggota legislatif, Daerah Pemilihan 3 di wakili orang $(42 \%)$ dari 7 orang $(58 \%)$ calon anggota legislatif, Daerah pemilihan 4 di wakili 2 orang $(40 \%)$ dari 5 orang calon anggota legislatif, Daerah Pemilihan 5 di wakili 3 orang $(42 \%)$ dari 7 orang (58\%) calon anggota legislatif. jumlah keseluruhan dari ke 5 Daerah Pemilihan tersebut keterwakilan perempuan Partai PKS melebihi kuota 30\% 14 orang $(42 \%)$ dari 33 oarang, semntara laki-laki yang mencalonkan anggota legislatif dari ke 5 derah pemilihan tersebut 19 orang ( $58 \%$ ) dari 33 calon anggota legislatif dari PKS. Meski demiakan perempuan dari PKS melebihi kuota 30\% dalam pencalonan legislatif tahun 2014 silam namun tidak ada satu oarangpun yang bisa mewakili perempuan dari PKS yang duduk di DPRD kabupaten Gorontalo, hal ini cukup menunjukan bahwa kinerja partai tidak optimal dalam memperjuangkan hak-hak Perempuan sehingga merupakan hal penting bagi partai untuk bekerja lebih lagi di pemilu yang akan datang.

Tabel. 2.

Calon Anggota Legislatif Partai Keadilan Sejahtera Kabupaten Gorontalo Berdasarkan Daerah Pemilihan

Tahun 2014-2019

\begin{tabular}{|c|c|c|c|c|c|c|c|c|c|c|}
\hline \multirow{3}{*}{$\begin{array}{c}\text { Jenis } \\
\text { Kelamin }\end{array}$} & \multicolumn{10}{|c|}{ Jumlah Keterwakilan } \\
\hline & \multicolumn{2}{|c|}{ DAPIL 1} & \multicolumn{2}{|c|}{ DAPIL 2} & \multicolumn{2}{|c|}{ DAPIL 3} & \multicolumn{2}{|c|}{ DAPIL 4} & \multicolumn{2}{|c|}{ DAPIL 5} \\
\hline & $\begin{array}{l}\text { Jlh } \\
\text { (7) }\end{array}$ & $(\%)$ & $\begin{array}{c}\mathrm{Jmlh} \\
(7)\end{array}$ & $(\%)$ & $\begin{array}{c}\mathrm{Jmlh} \\
(7)\end{array}$ & $(\%)$ & $\begin{array}{c}\mathrm{Jmlh} \\
(5)\end{array}$ & $(\%)$ & $\begin{array}{c}\text { Jmlh } \\
(7)\end{array}$ & $(\%)$ \\
\hline $\mathrm{L}$ & 4 & $\begin{array}{l}58 \\
\%\end{array}$ & 4 & $\begin{array}{l}58 \\
\%\end{array}$ & 4 & $\begin{array}{l}58 \\
\%\end{array}$ & 3 & $\begin{array}{l}60 \\
\%\end{array}$ & 4 & $\begin{array}{l}58 \\
\%\end{array}$ \\
\hline $\mathrm{P}$ & 3 & $\begin{array}{l}42 \\
\% \\
\end{array}$ & 3 & $\begin{array}{l}42 \\
\% \\
\end{array}$ & 3 & $\begin{array}{l}42 \\
\% \\
\end{array}$ & 2 & $\begin{array}{l}40 \\
\% \\
\end{array}$ & 7 & $\begin{array}{l}42 \\
\% \\
\end{array}$ \\
\hline
\end{tabular}

Data : KPU Kabupaten Gorontalo 
Dari tabel 2. di atas dapat dilihat bagaimana perbandingan keterwakilan perempuan yang mencalonkan anggota legislatif dari PKS sudah cukup terwakilkan artinya pemenuhan kuota 30\% sudah di lakukan oleh PKS itu sendiri namun ini belum menjawab keterwakilan perempuan di DPRD Kabupaten Gorontalo di karenakan belum ada satupun keterwakilan perempuan dari PKS yang menduduki kursi DPRD Kabupaten Gorontalo.

Dari wawancara yang dilakukan Penulis dengan Ibu Ervina Yamin, SE yang juga merupakan pengurus Partai Keadilan Sejahtera, diperoleh keterangan bahwa ada beberapa faktor yang mempengaruhi sehingga 30\% keterwakilan perempuan tersebut tidak terpenuhi, yaitu :

Faktor budaya. Bahwa selama ini budaya yang berkembang di Indonesia adalah budaya partiarki. Budaya partiarki adalah merupakan budaya dimana lelaki mempunyai kedudukan lebih tinggi dari wanita. Dalam budaya ini, ada perbedaan yang jelas mengenai tugas dan peranan wanita dan lelaki dalam kehidupan bermasyarakat, khususnya dalam keluarga. Jadi karena budaya ini yang menular bahwa laki-laki adalah pemimpin dalam keluarga, dan mempunyai otoritas kuat terhadap kontrol keluarga baik itu istri. Seorang istri tugasnya hanya di rumah, menjaga rumah, dan mengasuh anak. Karena budaya ini belum bisa hilang dari Indonesia sehingga sampai saat ini pemikiran masyarakat bahwa perempuan belum partas dan tidak cocok untuk menduduki jabatan publik atau duduk di dalam DPRD.

Faktor Partai itu sendiri. Partai terkadang tidak pernah memberikan kesempatan kepada perempuan untuk menduduki jabatan-jabatan strategis dalam kepengurusan partai, sehingga perempuan tersebut terkadang terabaikan. Jabatan seperti ketua umum, atau jabatan lainnya selalu didominasi oleh laki-laki. Dan perempuan selalu hanya diberikan kesempatan, kalau bukan menjadi seorang bendahara, pasti ditempatkan di bagian konsumsi. Jadi wajar kalau keterwakilan perempuan 30\% di dalam DPRD tidak terpenuhi. Partai politik mempunyai fungsi yaitu sebagai komunikasi politik dan sosialisasi politik. Dari kedua fungsi tersebut seharusnya partai politik memberikan selalu pendidikan politik kepada perempuan agar perempuan tersebut juga mendapatkan pendidikan hak-hak perempuan yang sebagaimana mestinya. Sehinga perempuan bisa dan mampu bersaing dengan laki-laki dalam hal kepengurusan maupun di dalam pencalonan anggota legislatif itu sendiri dan yang terutama perempuan mampu bersaing dalam hal pemenangan pemilu yang setiap 5 tahun sekali diadakan oleh Indonesia.

Faktor dari pribadi perempuan tersebut. Setiap perempuan Indonesia masih banyak pesimis ataupun merasa takut terhadap dirinya sendiri. Terkadang mereka merasa bahwa mereka tidak mempunyai kemampuan dapat menyaingi laki-laki dalam hal berpolitik. Motivasi dan dorongan moril masihlah sangat kurang di antara perempuan tersebut, sehingga mereka sulit untuk berkembang untuk ke depannya. Belum lagi di dalam sebuah partai politik tersebut dominasi perempuan sangatlah kecil sehingga mereka sulit untuk memperlihatkan dirinyadi depan, dibandingkan laki-laki.

Faktor perekrutan kader-kader perempuan yang berkualitas. Masyarakat Indonesia yangn merupakan masyarakat dengan adat timur seringkali menganggap bahwa dunia politik adalah ranah laki-laki, sehingga tidak selayaknya perempuan masuk ke dunia politik. Pemikiran semacam ini sebenarnya merupakan suatu pemikiran yang bias gender atau mencampur 
adukkan antara gender dan jenis kelamin. Padahal diantara keduanya berbeda. Permasalahan ini seringkali menjadi masalah pula bagi Partai Politik dalam merekrut kader-kader perempuan yang berkualitas. Ini menunjukan bahwa pendidikan politik masyarakat khususnya kaum perempuan masihlah kurang atau terlalu minim. Karena pandangan yang bias gender bahwa dunia politik adalah milik laki-laki akan menghambat affirmatif itu sendiri, meskipun telah dibuat suatu regulasi yang berpihak kepada perempuan. Namun kondisi ini menunjukan bahwa sesungguhnya Partai Politik sendiri telah gagal dalam menjalankan fungsinya. Fungsi yang dimaksud yaitu fungsi pendidikan politik sebagaimana diatur dalam pasal 31 Undang-Undang Nomor 2 tahun 2008 tentang partai Politik, “(1) Partai Politik melakukan pendidikan politik bagi masyarakat sesuai dengan ruang lingkup tanggung jawabnya dengan memperhatikan keadilan dan kesetaraan gender dengan tujuan antara lain :

a. peningkatkan kesadaran hak dan kewajiban masyarakat dalam kehidupan bermasyarakat, berbangsa, dan bernegara;

b. meningkatkan partisipasi politik dan inisiatif masyarakat dalam kehidupan bermasyarakat, berbangsa, dan bernegara;

c. meningkatkan kemandirian, kedewasaan, dan membangun karakter bangsa dalam rangka memelihara persatuan dan kesatuan bangsa. Pendidikan politik sebagaimana dimaksud pada ayat (1) dilaksanakan untuk membangun etika dan budaya politik sesuai dengan Pancasila." Jelas dan nyata bahwa Partai Politik memiliki fungsi untuk memberikan pendidikan politik kepada masyarakat agar dapat meningkatkan partisipasi politik dalam kehidupan perpolitikan Indonesia dengan keadilan gender sesuai dengan pancasila. Karena apabila fungsi pendidikan politik telah terlaksana dengan bak, seharusnya Partai Politik tidak mengalami kesulitan dalam merekrut kader-kader perempuan yang berkualitas.

Jadi 4 (empat) faktor tersebut merupakan faktor-faktor yang menjadi penghambat sehingga keterwakilan 30\% perempuan sangatlah sulit terpenuhi. Dan masih banyak lagi faktor-faktor penghambat lainya.

\section{PENUTUP}

\subsection{Kesimpulan}

Dari rumusan masalah, berdasarkan hasil penelitian dan pembahasan yang telah diuraikan di atas, maka Penulis dapat menarik kesimpulan sebagai berikut:

1. Dasar pertimbangan pada penentuan keterwakilan perempuan $30 \%$ dalam kepengurusan partai politik menurut Undang-Undang No. 2 Tahun 2008 Jo. Undang-Undang No. 2 Tahun 2011 tentang Partai Politik adalah : 1) Ditinjau dari perspektif hukum, bahwa di dalam UUD 1945 telah dijamin persamaan kedudukan antara setiap warga Negara dan bagaimana Negara memberikan perlakukan khusus terhadap warga negaranya yang diatur dalam Pasal 28D ayat (3) dan $28 \mathrm{H}$ ayat (2) UUD NRI Tahun 1945; 2) $30 \%$ keterwakilan perempuan dalam kepengurusan partai politik tersebut merupakan kebijakan hukum (legal policy) yang dituangkan dalam UU Partai Politik dan merupakan pemberian Negara dalam upaya meningkatkan partisipasi perempuan dalam politik; 3) Banyaknya konvensi-konvensi internasional yang telah diratifikasi Indonesia sehingga membuat bentuk-bentuk 
diskriminasi terhadap perempuan harus dihapuskan seperti Konvensi tentang Hak-hak Politik Wanita Tahun 1952 menjadi Undang-undang Nomor 68 Tahun 1958, dan sebagainya; dan 4) Dicantumkannya angka 30\% dalam UU No. 2 tahun 2008 Jo. UU No. 2 Tahun 2011 tentang partai politik adalah karena dorongan dari organisasi-organisasi perempuan yang ada di Indonesia dulu yaitu KPPI (Kaukus Perempuan Politik Indonesia) yang sangat mengupayakan agar perempuan juga mendapat tempat yang setara dengan laki-laki di dunia politik.

2. Ada empat faktor penghambat pemenuhan 30\% keterwakilan perempuan sampai hal tersebut tidak terpenuhi, yaitu : 1) Dari segi normatif, melihat Undang-Undang yang mengaturnya yaitu UU No. 2 Tahun 2008 Jo. UU No. 2 Tahun 2011 tentang partai politik bahwa di dalam undang-undang tersebut tidaklah efektif dalam proses implementasinya. Karena keharusan persyaratan 30\% keterwakilan perempuan hanya dalam sebuah kepengurusan partai politik, ini sesuai Pasal 2 ayat (2), ayat (5) dan Pasal 20. Sedangkan untuk duduk di Kursi DPR RI, tidak ada keharusan keterwakilan perempuan harus mencapai 30\%; 2) Faktor budaya, yaitu bahwa selama ini budaya yang berkembang di Indonesia adalah budaya patriarki. Budaya patriarki merupakan budaya dimana lelaki mempunyai kedudukan lebih tinggi dari wanita; 3) Faktor Partai Politik itu sendiri. Partai terkadang tidak pernah memberikan kesempatan kepada perempuan untuk menduduki jabatan-jabatan strategis dalam kepengurusan partai, sehingga perempuan tersebut terkadang terabaikan; dan 4) Faktor dari pribadi perempuan tersebut. Perempuan Indonesia masih banyak yang pesimis ataupun merasa takut terhadap dirinya sendiri.

\subsection{Saran}

Berdasarkan kesimpulan tersebut di atas, maka Penulis mengajukan saran sebagai berikut :

1. Dalam memberikan pertimbangan 30\% keterwakilan perempuan, harusnya pembentuk undang-undang yaitu Pemerintah dan DPR RI senantiasa melihat realitas bahwa 30\% keterwakilan perempuan tersebut tidak terpenuhi. Maka UU yang mengatur hal tersebut seharusnya perlu pendalaman ulang dan direvisi demi perbaikan yang ada.

2. Banyaknya faktor penghambat pemenuhan $30 \%$ keterwakilan perempuan tersebut seharusnya membuat partai politik lebih bekerja keras untuk memberikan pendidikan politik dan sosialisasi politik kepada masyarakat khususnya perempuan dalam upaya peningkatan partisipasi perempuan di bidang politik. Karena partai politik mempunyai fungsi dan tugas untuk melakukan hal tersebut.

\section{DAFTAR PUSTAKA}

Alfian. 1978. Pemikiran dan Perubahan Politik Indonesia.Jakarta : Yayasan Ilmu-Ilmu Sosial dan PT. Gramedia.

Anugrah, Astrid. "Keterwakilan Perempuan dalam Politik" cetakan ke-2 Pancuran Alam Jakarta mie 2009

Budiardjo, Miriam (ed). 1981. Partisipasi dan Partai Politik: Sebuah bunga rampai. Jakarta : PT. Gramedia. 
Djoharwinarlien, Sri. "Dilema Kesetaraan Gender: Repfleksi dan Respons Praktis". Cetekan ke-1, September 2012, Yogyakarta.

Fakih, Mansour, "Analisa Gender", Pustaka Pelajar Yogyakarta 1996.

Irsyam, Mahrus, dkk, "Menggugat Partai Politik", (Jakarta, LIP FISIP UI, 2003)

Hadiz Liza, "perempuan dalam wacana politik orde baru" Pustaka LP3ES Indonesia Jakarta 2004.

Gaffar, Afan, "Politik Indonesia Transisi Menuju Demokrasi", cetakan ke-5, Yokyakarta, September, 2006.

Suwondo, Nani. 1981. Kedudukan Wanita Indonesia dalam Hukum dan Masyarakat. Jakarta: Ghalia Indonesia.

Tan, Melly G (ed). 1991. Perempuan Indonesia Pemimpin Masa Depan ?. Jakarta : Pustaka Sinar Harapan.

Yudhi Presetya, Imam, "pergeseran idiologi dalam partai politik", jurnal, Fakultas Ilmu Sosial dan Politik Universitas Matirim Raja Ali., Haji Vol. 1, No, 1, 2011.

Kelompok Perundang-Undangan

Undang-Undang Dasar Negara Republik Indonesia Tahun 1945.

Undang-Undang No. 10 Tahun 2008 tentang Pemilu.

Undang-Undang No. 2 Tahun 2011 tentang Partai Politik. 